\title{
PENGATURAN HAK ATAS LINGKUNGAN HIDUP TERHADAP KESEHATAN
}

Oleh :

Rosmidah Hasibuan, S.Pd, M.Si

Dosen Tetap STKIP Labuhan Batu

\begin{abstract}
ABSTRAK
Kesehatan Lingkungan sebagai salah satu upaya kesehatan ditujukan untuk mewujudkan kualitas lingkungan yang sehat, baik fisik, kimia, biologi, maupun sosial yang memungkinkan setiap orang mencapai derajat kesehatan yang setinggi-tingginya sebagaimana tercantum dalam Pasal 162 Undang-Undang Nomor 36 Tahun 2009 tentang Kesehatan. Ada keterkaitan langsung antara perlindungan hak asasi manusia terhadap lingkungan hidup. Lingkungan hidup merupakan bagian yang mutlak dari kehidupan manusia. Dengan kata lain lingkungan hidup tidak terlepas dari kehidupan manusia. Adapun peraturan yang mengatur dalam hal lingkungan hidup yaitu UndangUndang Nomor 32 Tahun 2009 tentang Perlindungan dan Pengelolaan Lingkungan Hidup. Demikian juga tentang kesehatan lingkungan diatur dengan Peraturan Pemerintah Nomor 66 Tahun 2014 Tentang Kesehatan Lingkungan. Dan ditindak lanjuti dengan Peraturan Menteri Kesehatan Nomor 32 Tahun 2017 tentang standar baku mutu kesehatan lingkungan dan persyaratan kesehatan air untuk keperluan higiene sanitasi, kolam renang, solus per aqua, dan pemandian umum.
\end{abstract}

Kata Kunci: Pengaturan, lingkungan, kesehatan.

\section{PENDAHULUAN}

\subsection{Latar Belakang}

Lingkungan hidup adalah kesatuan ruang dengan semua benda, daya, keadaan, dan makhluk hidup, termasuk manusia dan perilakunya, yang mempengaruhi alam itu sendiri, kelangsungan perikehidupan, dan kesejahteraan manusia serta makhluk hidup lain (Pasal 1 UU No. 32 Tahun 2009).

Lingkungan hidup merupakan akumulasi dari interaksi berbagai faktor yang terkandung dalam lingkungan biotik dan abiotik. Lingkungan biotik merupakan kesatuan makhluk hidup, seperti mikroorganisme, manusia, tumbuhan, dan hewan. Adapun lingkungan abiotik merupakan kondisi yang terdapat di lingkungan sekitar berupa benda mati, seperti mineral, batuan, tanah, air dan udara (https://www.zonasiswa.com/2014/10/lin gkungan-hidup.html).

Lingkungan merupakan hal utama dalam pencapaian terhadap kesehatan bagi manusia. Apabila lingkungan baik dan bersih maka kesehatan masyarakat juga akan baik, namun demikian apabila lingkungan buruk maka akan mempengaruhi terhadap kesehatan yang buruk juga.

Kesehatan Lingkungan sebagai salah satu upaya kesehatan ditujukan untuk mewujudkan kualitas lingkungan yang sehat, baik fisik, kimia, biologi, 
maupun sosial yang memungkinkan setiap orang mencapai derajat kesehatan yang setinggi-tingginya sebagaimana tercantum dalam Pasal 162 UndangUndang Nomor 36 Tahun 2009 tentang Kesehatan. Kesehatan Lingkungan diselenggarakan melalui upaya Penyehatan, Pengamanan, dan Pengendalian, yang dilakukan terhadap lingkungan Permukiman, Tempat Kerja, tempat rekreasi, serta tempat dan fasilitas umum.

Dalam Konstitusi dasar Indonesia yang tertuang pada UUD 1945 Pasal $28 \mathrm{H}$ Ayat 1, menyebutkan bahwa,"“Setiap orang berhak hidup sejahtera lahir dan batin, bertempat tinggal dan mendapatkan lingkungan hidup yang baik dan sehat serta berhak mendapatkan pelayanan kesehatan". Hak atas lingkungan hidup yang baik dan sehat, juga ditegaskan dalam Undang-Undang Nomor 32 Tahun 2009 tentang Perlindungan dan Pengelolaan Lingkungan Hidup (UUPPLH).

\subsection{Perumusan Masalah}

Berdasarkan latar belakang masalah yang telah diuraikan, maka perumusan masalah yaitu tentang bagaimana pengaturan terhadap lingkungan hidup bagi kesehatan manusia untuk mencapai hidup yang sehat dan sejahtera?
II. KETENTUAN

TENTANG

\section{LINGKUNGAN HIDUP DAN KESEHATAN}

Pengaturan tentang hukum lingkungan di Indonesia dimulai sejak diundangkannya Undang-Undang No. 4 Tahun 1982 Tentang KetentuanKetentuan Pokok Pengelolaan Lingkungan Hidup, tanggal 11 Maret 1982 yang biasa disingkat dengan sebutan UULH 1982. Selanjutnya pada tanggal 19 September 1997 digantikan oleh Undangundang No. 23 Tahun 1997 dan kemudian UU No. 23 Tahun 1997 (UULH 1997) juga dinyatakan tidak berlaku oleh UU No. 32 Tahun 2009 tentang Perlindungan dan Pengelolaan Lingkungan Hidup (LN tahun 209 No. 140, disingkat dengan UUPPLH).

Hukum lingkungan merupakan bidang hukum yang disebut dengan bidang hukum fungsional, yaitu sebuah bidang hukum yang mengandung ketentuanketentuan hukum administrasi negara, pidana dan perdata. Sebab jika kita cermati ketiga baik UULH 1982, UULH 1997 maupun UUPPLH 2009 mengandung norma-norma undangundang yang masuk ke dalam bidang hukum administrasi negara, pidana dan perdata. Oleh sebab itu, disegala aspeknya, maka hukum lingkungan akan senantiasa bersinggungan dengan hak-hak dasar manusia, baik itu secara administratif (mis: izin mendirikan 
bangunan/hak bertempat tinggal), perdata

(terkait hak untuk mendapatkan ganti kerugian), maupun pidana.

Sesuai dengan Pasal 65 ayat (1) s/d ayat 5 maka dapat ditemukan suatu fakta bahwa hak-hak yang tedapat dalam bidang lingkungan hidup adalah : a. hak atas lingkungan hidup yang baik dan, b. hak mendapatkan pendidikan lingkungan hidup, c. hak untuk mengakses informasi, akses partisipasi dan akses keadilan dalam memenuhi hak atas lingkungan hidup yang baik dan sehat, d. hak mengajukan usul dan / atau keberatan terhadap rencana usaha dan / atau kegiatan yang diperkirakan dapat menimbulkan dampak terhadap lingkungan hidup, e. hak untuk berperan dalam perlindungan dan pengelolaan lingkungan hidup f. hak melakukan pengaduan akibat dugaan pencemaran dan / atau perusakan lingkungan hidup (Ashabul Kahfi, 2013).

Ada beberapa hal yang menyebabkan agar tujuan pngelolaan lingkungan hidup dapat tercapai. 1) Memperkuat kontrol sosial masyarakat melalui pengembangan, transparansi, dan peran serta masyarakat, terutama dalam proses pengambilan keputusan. 2) Keadilan bagi rakyat dalam pemanfaatan lingkungan. Setiap keputusan yang diambil haruslah melibatkan dan demi kesejahteraan rakyat banyak. Masyarakat diberikan akses dalam pengelolaan lingkungan seluas-luasnya. 3)
Penyederhanaan prosedur (Sriyanto, 2007).

Menurut Siti Sundari Rangkuti (2005:12), persyaratan untuk melaksanakan kebijaksanan lingkungan (sumberdaya alam) adalah pembinaan peraturan perundang-undangan yang tangguh, dipersiapkan secara cermat dengan memperhitungkan unsur keterpaduan dalam sistem pengaturan, sehingga efektivitasnya dapat tercapai secara maksimal.

$$
\text { Lingkungan yang baik }
$$

mempengaruhi terhadap kesehatan bagi manusia atau penghuni disekelilingnya. Lingkungan mempunyai peranan yang penting bagi kesehatan, sehingga lingkumgan dan kesehatan saling berhubungan satu sama lain. Agar lingkungan terjaga dengan baik diperlukan adanya pengaturan dalam bentuk hukum.

Hukum Perlindungan Lingkungan tidak mengenal satu bidang kebijaksanaan, akan tetapi merupakan kumpulan dari peraturan perundang undangan di bidang pengelolaan lingkungan hidup yang berkaitan dengan lingkungan biotik sampai batas tertentu juga dengan lingkungan antrophogen. Sedang kalau wujud struktural hukum perlindungan lingkungan meliputi perlindungan hayati, non hayati, buatan termasuk cagar budaya seperti nampak pada UU No.5 Tahun 1990 tentang 
Konservasi Sumber Daya Alam dan Ekosistemnya, kemudian UU No. 5 Tahun 1992 tentang Cagar Budaya.

Hukum Kesehatan Lingkungan adalah hukum yang berhubungan dengan kebijaksanaan di bidang kesehatan lingkungan dan wujud strukturalnya meliputi pemeliharaan kondisi air, tanah, dan udara seperti pada PP No.35 Tahun 1991 tentang Sungai.Hukum Pencemaran Lingkungan merupakan hukum yang memiliki pengaturan terhadap pencegahan dan penanggulangan pencemaran. Wujud pola hukum pencemaran lingkungan ini meliputi pencemaran air, udara, tanah seperti PP No.12 Tahun 1995 tentang Pengelolaan Limbah B3. (http://repository.usu.ac.id/bitstream/hand le/123456789/58289/Chapter\%20II.pdf?s equence $=3$ )

Ketentuan tentang kesehatan diatur dalam Undang-Undang kesehatan Nomor 36 Tahun 2009 merupakan revisi dari Undang -Undang nomor 23 tahun 2002 yang disahkan pada tanggal 13 Oktober tahun 2009. Dalam undang-undang, banyak memberikan peluang bagi peningkatan pembangunan kesehatan, karena pemerintah pusat wajib untuk mengalokasikan $5 \%$ APBN untuk pembiayaan kesehatan begitu pula pemerintah daerah baik propinsi maupun kabupaten/kota wajib untuk menyediakan $10 \%$ APBD untuk pembiayaan kesehatan. Dengan demikian maka pemerintah pusat dan daerah minimal harus mengalokasikan anggaran $30 \%$ untuk pendidikan dan kesehatan, jika hal ini dapat terpenuhi maka harus diimbangi dengan peningkatan status pendidikan dan kesehatan yang optimal.

Di sisi lain, Undang-Undang Kesehatan yang baru ini (UU No. 36 tahun 2009) tidak memuat konsep yang jelas tentang "kesehatan masyarakat" Sebagaimana inti dari paradigma sehat, yaitu pendekatan promotif dan preventif yang tentunya sasaran utamanya adalah masyarakat.Karena masyarakat sendiri tidak dicantumkan dalam ketentuan umum dalam undang-undang kesehatan terbaru ini, sehingga undang-undang kesehatan terlihat hanya di peruntukkan untuk pemerintah pusat dan daerah termasuk petugas kesehatan sebagai payung hukum untuk menyelenggarakan pembangunan kesehatan. Tetapi tidak diperuntukkan untuk masyarakat sebagai pemilik kesehatan, pemilik partisipatif, pemilik investasi kesehatan, pemilik hak asasi kesehatan dan sebagai subjek pembangunan kesehatan. Kewajiban atau tanggung jawab masyarakat itu sendiri tidak ditemukan, yang ada hanya peran serta masyarakat. (http://bgfunhas.blogspot.com/2013/01/analisi $\underline{\text { s-undang-undang-kesehatan-no-36.html) }}$

Menurut organisasi kesehatan dunia (WHO) Kesehatan Lingkungan adalah suatu keseimbangan ekologi yang harus ada di antara manusia dan lingkungannya agar dapat menjamin keadaan sehat dari manusia. 
Sedangkan menurut Peraturan Pemerintah

Nomor 66 Tahun 2014 tentang Kesehatan

Lingkungan, Pasal 1 point 1 menyebutkan bahwa Kesehatan Lingkungan adalah upaya pencegahan penyakit dan/atau gangguan kesehatan dari faktor risiko lingkungan untuk mewujudkan kualitas lingkungan yang sehat baik dari aspek fisik, kimia, biologi, maupun sosial.

Tanggung jawab terhadap kesehatan lingkungan diatur dalam pasal 3 PP No. 66 Tahun 2014 yaitu Pemerintah, pemerintah daerah provinsi, dan pemerintah daerah kabupaten/kota bertanggung jawab untuk:

a. menjamin tersedianya lingkungan yang sehat untuk mencapai derajat kesehatan yang setinggi-tingginya sesuai dengan kewenangannya;

b. mengatur, membina, dan mengawasi penyelenggaraan Kesehatan Lingkungan; dan

c. memberdayakan dan mendorong peran aktif masyarakat dalam penyelenggaraan Kesehatan Lingkungan.

Dalam pengendalian kesehatan liungkungan terdapat standar baku mutu kesehatan lingkungan sebagaimana diatur dalam PP No. 66 Tahun 2014 serta diatur lebih lanjut dalam Peraturan Menteri Kesehatan Republik Indonesia Nomor 32 Tahun 2017 tentang standar baku mutu kesehatan lingkungan dan persyaratan kesehatan air untuk keperluan higiene sanitasi, kolam renang, solus per aqua, dan pemandian umum.
III. HAK ATAS LINGKUNGAN HIDUP YANG SEHAT

Undang-Undang Dasar Negara

Republik Indonesia Tahun 1945, deklarasi hak asasi manusia internasional serta undang-undang lingkungan hidup Republik Indonesia telah mengamanahkan hak setiap warga negara salah satunya adalah hak atas lingkungan yang baik dan sehat. oleh karena itu perlu adanya sinergitas dan kerjasama antara pemerintah, pemerintah daerah dan masyarakat dalam mengelola dan melindungi kualitas lingkungan hidup agar hak atas lingkungan hiduo yang baik dan sehat dapat terwujud demi kemakmuran dan kesejahteraan masyarakat Indonesia. Selain mempunyai hak atas lingkungan yang baik dan sehat manusia juga mempunyai kewajiban untuk menjaga lingkungan untuk tetap menjadi lingkungan hidup yang baik dan sehat.

Pasal 1 Undang-Undang Nomor 39 Tahun 1999 tentang HAM disebutkan bahwa "Hak Asasi Manusia adalah seperangkat hak yang melekat pada hakekat dan keberadaan manusia sebagai makhluk Tuhan Yang Maha Esa dan merupakan anugerah-Nya yang wajib dihormati, dijunjung tinggi, dan dilindungi oleh negara, hukum, pemerintah dan setiap orang, demi kehormatan serta perlindungan harkat dan martabat manusia". 
Pengertian "Lingkungan Hidup yang Baik dan Sehat", mengandung makna lingkungan yang dapat memungkinkan manusia berkembang secara optimal, secara selaras, serasi, dan seimbang. Adanya jaminan semacam ini memberi kemungkinan bagi setiap orang untuk menuntut kepada pemerintah agar "kebaikan dan kesehatan lingkungannya perlu diperhatikan dan ditingkatkan terus dan oleh karenanya pula adalah merupakan kewajiban bagi negara untuk selalu menciptakan lingkungan hidup yang baik dan sehat bagi warganya dan secara terus menerus melakukan usahausaha perbaikan dan penyehatan lingkungan hidup.

Penempatan Hak atas lingkungan hidup yang baik dan sehat mempunyai arti penting dan hakiki sebagai hak warga Negara, dalam hal ini Negara sebagai penguasa harus menjamin dan melindungi hak warga atas lingkungan. Jika dikaji lebih didalam undang-undang lingkungan yang lama yakni UU No. 23 Tahun 1997 tentang Pengelolaan Lingkungan Hidup (UUPLH), ini jelas membedakan kedudukan hak atas lingkungan hidup yang baik dan sehat, dimana diatur pada Pasal 5 ayat 1 UU No. 23 Tahun 1997, menyebutkan bahwa "Setiap orang mempunyai hak yang sama atas lingkungan hidup yang baik dan sehat". Sedangkan UUPPLH lebih menempatkan hak atas lingkungan yang baik dan sehat pada filosofi dari dasar pembentukan perubahan undang-undang lingkungan hidup yang baru. Disini hak atas lingkungan yang baik dan sehat ditempatkan pada posisi paling tinggi sebagai hak dasar warga yang dijamin oleh Negara. Perbedaan lain yang mendasar atas UU No. 23 Tahun 1997 dengan UU No. 32 Tahun 2009, yakni penguatan yang terdapat dalam UU PPLH tentang prinsip-prinsip perlindungan dan pengelolaan lingkungan yang didasarkan pada tata kelola pemerintahan yang baik karena dalam setiap proses perumusan dan penerapan instrument pencegahan pencemaran dan/atau kerusakan lingkungan hidup serta penanggulangnya dan penegakan hokum mewajibkan pengintegrasian aspek transparansi, partisipasi, akuntabilitas, dan keadilan. (https://gagasanhukum.wordpress.com/20 10/09/30/hak-atas-lingkungan-hidupyang-baik-dan-sehat-di-kaltim/).

Hak atas lingkungan hidup yang baik dan sehat sebagaimana yang telah dituangkan dalam Pasal 28 piagam hak asasi manusia sebagai bagian tak terpisahkan dari ketetapan MPR RI no. XVII/MPR/1998 tentang hak asasi manusia yang menyatakan : "setiap orang berhak atas lingkungan hidup yang baik dan sehat". Selanjutnya pada tanggal 18 agustus 2000 perubahan kedua UUD 1945 merumuskan hak termaksud dalam pasal $28 \mathrm{H}$ ayat (1) menyatakan : "Setiap orang 
berhak hidup sejahtera lahir dan batin, bertempat tinggal, dan mendapatkan lingkungan hidup yang baik dan sehat serta berhak memperoleh pelayanan kesehatan". Pada tahun 1999 keluarlah undang-undang nomor 39 tahun 1999 tentang hak asasi manusia yang dalam pasal 9 ayat (3) menegaskan : "setiap orang berhak atas lingkungan hidup yang baik dan sehat". Hal ini juga dituangkan dalam pasal 5 ayat 1 UU No.23 Tahun 1997 dan lebih diperdalam pemaknaan pada landasan filosofi hak atas lingkungan hidup yang baik dan sehat pada UU No.32 Tahun 2009.

Dengan demikian, ada keterkaitan langsung antara perlindungan hak asasi manusia terhadap lingkungan hidup. Lingkungan hidup merupakan bagian yang mutlak dari kehidupan manusia. Dengan kata lain lingkungan hidup tidak terlepas dari kehidupan manusia. Manusia mencari makan dan minum serta memenuhi kebutuhan lainnya dari ketersediaan atau sumber-sumber yang diberikan oleh lingkungan hidup dan kekayaan alam sebagai sumber pertama dan terpenting bagi pemenuhan berbagai kebutuhnnya. Dengan ini perlu adanya kesadaran yang tinggi bagi masyarakat ataupun pemerintah yang berwenang untuk tetap menjaga lingkungan hidup yang baik dan sehat.

\section{KESIMPULAN DAN SARAN}

\subsection{Kesimpulan}

1. Lingkungan yang baik mempengaruhi terhadap kesehatan bagi manusia atau penghuni disekelilingnya. Lingkungan mempunyai peranan yang penting bagi kesehatan, sehingga lingkumgan dan kesehatan saling berhubungan satu sama lain. Agar lingkungan terjaga dengan baik diperlukan adanya pengaturan dalam bentuk hukum. Adapun pengaturan tentang lingkungan diatur dalam Undang-Undang Nomor 32 Tahun 2009 tentang Perlindungan dan Pengelolaan Lingkungan Hidup. Dalam UndangUndang tersebut menyebutkan bahwa lingkungan hidup adalah kesatuan ruang dengan semua benda, daya, keadaan, dan makhluk hidup, termasuk manusia dan perilakunya, yang mempengaruhi alam itu sendiri, kelangsungan perikehidupan, dan kesejahteraan manusia serta makhluk hidup lain. Sedangkan pengaturan tentang kesehatan diatur dalam UndangUndang Nomor 36 Tahun 2009 tentang Kesehatan. Demikian juga tentang kesehatan lingkungan diatur dengan Peraturan Pemerintah Nomor 66 Tahun 2014 Tentang Kesehatan Lingkungan. Dan 
ditindak lanjuti dengan Peraturan

Menteri Kesehatan Nomor 32

Tahun 2017 tentang standar baku mutu kesehatan lingkungan dan persyaratan kesehatan air untuk keperluan higiene sanitasi, kolam renang, solus per aqua, dan pemandian umum.

2. Hak atas lingkungan hidup yang baik dan sehat diatur dalam Pasal 1 Undang-Undang Nomor 39 Tahun 1999 tentang HAM disebutkan bahwa "Hak Asasi Manusia adalah seperangkat hak yang melekat pada hakekat dan keberadaan manusia sebagai makhluk Tuhan Yang Maha Esa dan merupakan anugerah-Nya yang wajib dihormati, dijunjung tinggi, dan dilindungi oleh negara, hukum, pemerintah dan setiap orang, demi kehormatan serta perlindungan harkat dan martabat manusia". Penempatan Hak atas lingkungan hidup yang baik dan sehat mempunyai arti penting dan hakiki sebagai hak warga Negara, dalam hal ini Negara sebagai penguasa harus menjamin dan melindungi hak warga atas lingkungan yang sehat.

\subsection{Saran}

1. Diperlukan adanya ketegasan dari pemerintah baik pusat, propinsi maupun daerah untuk menjalankan peraturan tentang lingkungan hidup terhadap kesehatan masyarakat dan Memberikan sanksi yang tegas terhadap para pelanggar terhadap kesehatan lingkungan hidup;

2. Memberikan hak atas lingkungan yang sehat terhadap masyarakat secara luas.

\section{DAFTAR PUSTAKA}

Ashabul Kahfi, Jaminan Konstitusional Terhadap Hak Atas Lingkungan Hidup Di Indonesia, Jurnal Aldaulah Vol. 2 / No. 2 / Desember 2013

https://gagasanhukum.wordpress.com/2010/0 9/30/hak-atas-lingkungan-hidup-yangbaik-dan-sehat-di-kaltim/ tanggal akses 10 September 2018

https://www.zonasiswa.com/2014/10/lingkun gan-hidup.html/ tanggal akses 10 september 2018

http://repository.usu.ac.id/bitstream/handle/12 3456789/58289/Chapter\%20II.pdf?sequ $\underline{\text { ence }=3}$, tanggal diakses 10 September 2018

http://bgfunhas.blogspot.com/2013/01/analisis -undang-undang-kesehatan-no-36.html tanggal diakses 10 September 2018

Peraturan Pemerintah Nomor 66 Tahun 2014 Tentang Kesehatan Lingkungan.

Peraturan Menteri Kesehatan Nomor 32 Tahun 2017 tentang standar baku mutu kesehatan lingkungan dan persyaratan kesehatan air untuk keperluan higiene sanitasi, kolam renang, solus per aqua, dan pemandian umum.

Sriyanto, Kondisi Lingkungan Hidup Di Jawa Tengan Dan Prospek Pembangunan Ke 
Depan, Jurnal Geografi, Volume 4 Nomor 2 Juli 2007

Siti Sundari Rangkuti, Hukum Lingkungan dan Kebijaksanaan Lingkungan, Edisi ketiga, Airlangga University Press, Surabaya, 2005.

Undang-Undang Dasar Tahun 1945
Undang-Undang Nomor 32 Tahun 2009 tentang Perlindungan dan Pengelolaan Lingkungan Hidup

Undang-Undang Nomor 36 Tahun 2009 tentang Kesehatan. 